\title{
Modeling debris-flow runout patterns on two alpine fans with different dynamic simulation models
}

\author{
K. Schraml ${ }^{1}$, B. Thomschitz ${ }^{1}$, B. W. McArdell ${ }^{2}$, C. Graf ${ }^{2}$, and R. Kaitna ${ }^{1}$ \\ ${ }^{1}$ Institute of Mountain Risk Engineering, University of Natural Resources and Life Sciences, 1190 Vienna, Austria \\ ${ }^{2}$ Swiss Federal Research Institute WSL, Zürcherstrasse 111, 8903 Birmensdorf, Switzerland \\ Correspondence to: K. Schraml (klaus.schraml@boku.ac.at)
}

Received: 29 January 2015 - Published in Nat. Hazards Earth Syst. Sci. Discuss.: 13 February 2015

Revised: 18 May 2015 - Accepted: 23 May 2015 - Published: 02 July 2015

\begin{abstract}
Predicting potential deposition areas of future debris-flow events is important for engineering hazard assessment in alpine regions. To this end, numerical simulation models are commonly used tools. However, knowledge of appropriate model parameters is essential but often not available. In this study we use two numerical simulation models, RAMMS-DF (rapid mass movement system-debris-flow) and DAN3D (dynamic analysis of landslides in three dimensions), to back-calculate two well-documented debris-flow events in Austria and to compare the range and sensitivity of input parameters for the Voellmy flow model. All simulations are based on the same digital elevation models and similar boundary conditions. Our results show that observed deposition patterns are best matched with a parameter set of $\mu[-]$ and $\xi\left[\mathrm{m} \mathrm{s}^{-2}\right]$, ranging between 0.07 to 0.11 and 200 to $300 \mathrm{~m} \mathrm{~s}^{-2}$, respectively, for RAMMS-DF, and between 0.07 to 0.08 and 300 to $400 \mathrm{~m} \mathrm{~s}^{-2}$, respectively, for DAN3D. Sensitivity analysis shows a higher sensitivity of model parameters for the DAN3D model than for the RAMMS-DF model. This contributes to the evaluation of realistic model parameters for simulation of debris-flows in steep mountain catchments and highlights the sensitivity of the models.
\end{abstract}

\section{Introduction}

Debris-flows are mass wasting processes which occur in alpine regions and regularly cause loss of human life and property. It is therefore of great public and private interest to delineate hazardous areas where future debris-flows are expected to occur. For this, various types of simulation models provide useful guidance and are often used in engineering practice. Such models range from purely empirical-statistical approaches (e.g.,, Scheidegger, 1973; Körner, 1976; Rickenmann, 1999; Legros, 2002; Scheidl and Rickenmann, 2010) to more physically based, deterministic approaches, mostly based on depth-averaged flow equations and a simple flow resistance term (e.g., Takahashi, 1991; Hungr, 1995; O’Brien et al., 1993; Medina et al., 2008; Christen et al., 2010a, b).

Independent of the constitutive relation used, a common caveat for all numerical simulation tools remains model calibration (i.e., appropriate choice of flow-resistance parameters). In the case of simple stress-strain relations (e.g., Bingham, Herschel Bulkley model), laboratory experiments have been conducted to derive material parameters for highly concentrated grain-fluid mixtures (e.g., Phillips and Davies, 1991; Major and Pierson, 1992; Contreras and Davies, 2000; Kaitna and Rickenmann, 2007; Kaitna et al., 2007). However, direct application of the results is complicated because scaled experiments together with the simple flow resistance models do not themselves represent full mixture dynamics of a real scale debris-flow (Iverson, 1997, 2003; Ancey, 2006; Kaitna et al., 2014). Therefore, as for conceptual depth-averaged flow resistance approaches (Voellmy model, Coulomb, etc.), model parameterization based on the back-calculation of well-documented past events appears to be preferable for engineering application (e.g., Hungr et al., 2005; Rickenmann et al., 2006; Hürlimann et al., 2008; Christen et al., 2010a).

Comparative studies indicate that the Voellmy model (detailed in Sect. 2), which was originally developed for modeling bulk flow propagation of snow avalanches, is also suitable for modeling other geomorphic processes, including 
rock avalanches and debris-flows (e.g., Hungr, 1995; Revellino et al., 2004; Naef et al., 2006; Sosio et al., 2008; Deline et al., 2011). For snow avalanches, a reasonable database of model parameters for different types of snow and land cover is available (e.g., Bartelt et al., 2013a). However, there is much less experience in the case of debris-flows.

We therefore present our experiences with backcalculating Voellmy parameters for two well-documented debris-flow events in Austria. We do this using the simulation platforms, RAMMS-DF (rapid mass movement systemdebris-flow) and DAN3D (dynamic analysis of landslides in three dimensions). Because a plausible representation of simulation results requires knowledge of the sensitivity of model input parameters, we additionally carried out a comparative sensitivity analysis for both models. Section 2 gives a brief overview of the technical background of RAMMS-DF and DAN3D, the Voellmy model and the application to the two study sites. The best-fit parameters and the sensitivity analyses are presented in Sect. 3 and discussed in Sect. 4.

\section{Methodology and study area}

\subsection{Study sites}

Reiselehnrinne Creek is located in the Pitztal Valley, southwest of Innsbruck, Tyrol, Austria $\left(46^{\circ} 59^{\prime} \mathrm{N}, 10^{\circ} 52^{\prime} \mathrm{E}\right)$ (Fig. 1a). The catchment extends from 3343 to $1620 \mathrm{~m}$ a.s.l. and covers an area of $0.7 \mathrm{~km}^{2}$. The source area of the catchment is dominated by gneiss and mica schists. The middle, channelized part of the watershed consists of debrisoverlaying bedrock, whereas coarse debris-flow material comprises the fan (Kogelnig-Mayer et al., 2011). Data from a rain gauge located in Plangeross (1620 $\mathrm{m}$ a.s.l.) show that annual rainfall varies between 600 and $1150 \mathrm{~mm}$. Detailed information on the long-term event history of this site can be found in Kogelnig-Mayer et al. (2011), who reconstructed several debris-flows and snow avalanches during the last century using dendro-geomorphic methods. The best documented debris-flow event occurred in August 2009 and deposited around $20000-25000 \mathrm{~m}^{3}$ of material on the orographic right side of the fan and ran out onto the provincial road, which was subsequently blocked for several hours. This event was back-calculated within the present study.

The second study area is the densely forested fan of Festeticgraben Creek, situated in the Gesäuse National Park, Styria, Austria $\left(47^{\circ} 35^{\prime} \mathrm{N}, 14^{\circ} 38^{\prime} \mathrm{E}\right)$. The Festeticgraben Creek extends from the Planspitze summit $(2117 \mathrm{~m}$ a.s.l.) to $570 \mathrm{~m}$ a.s.l. at the confluence of the Enns River opposite the small village of Gstatterboden (Fig. 1b). The small catchment area $\left(0.7 \mathrm{~km}^{2}\right)$ is dominated by Triassic limestone (Dachsteinkalk) and dolomites and the material deposited on the fan has a mean grain size of $84 \mathrm{~mm}$. A rain gauge in the village of Gstatterboden, opposite the fan, recorded a mean annual precipitation between 1000 and $1700 \mathrm{~mm}$.

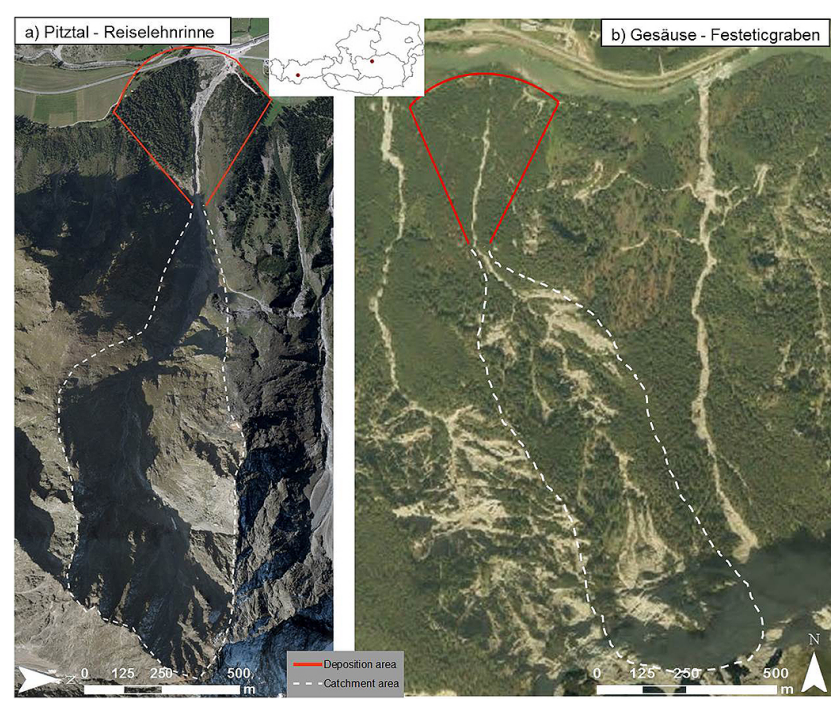

Figure 1. (a) The Reiselehnrinne Creek in the Pitztal study area in the western part of Austria, and (b) Festeticgraben Creek (source aerial photo: GIS-Steiermark, 2013) in the eastern part of the Austrian Alps. The catchment areas (white dashed lines) are defined as the source zones and deliver material to the fans (red solid lines).

Schraml et al. (2015) reconstructed debris-flow events on several gullies of the steep Planspitze north face through dendro-geomorphic techniques, including an event chronology of the Festeticgraben debris fan, as well as information on the geology and forest stand of the northern Planspitze area. In this study we focus on the most recent event, for which material deposited on the forested fan widely spread on both sides of the channel. Our back-calculation was for the 2006 event. Through field investigation we estimated a total volume of $\sim 10000 \mathrm{~m}^{3}$ deposited on the fan. We assume that the evenly distributed forest stand influenced the debrisflow deposition behavior, which we attempted to account for in our simulations.

\subsection{Simulation tools and friction relation}

Within this study, the numerical simulation tools RAMMSDF (developed at the WSL Institute for Snow and Avalanche Research SLF and the Swiss Federal Institute for Forest, Snow and Landscape Research WSL) and DAN3D (developed at the Department of Earth, Ocean and Atmospheric Sciences at the University of British Columbia UBC) were applied to replicate the deposition patterns of two welldocumented debris-flow events. Both simulation tools use the equivalent fluid concept (Hungr, 1995) and assume constant density and incompressibility of the flowing media as well as the validity of the shallow water approximation (i.e., negligible slope, normal accelerations). Mass and momentum balance is provided by solving the depth-averaged flow equations in a Lagrangian reference framework for DAN3D (Hungr and McDougall, 2009) and with a fixed Eulerian 
coordinate system for RAMMS (Christen et al., 2010b). A number of studies can be found in literature in which similar depth-averaged equations were derived, such as Iverson and Denlinger (2001) and Pastor et al. (2002) for Eulerian forms, and e.g., Savage and Hutter (1989) and Gray et al. (1999) for Lagrangian forms.

RAMMS uses the total variation diminishing (TVD) finite volume scheme (FVM) applied on 3D terrain (Christen et al., 2005; Graf and McArdell, 2008). By this method, averaged cell values are calculated for each place in a grid by the means of the edge fluxes from the neighboring cells (Toro, 1999). Detailed information on the discretization technique and the numerical background of RAMMS can be found in Christen et al. (2008, 2010a, b). The frictional behavior in $x$ and $y$ is represented by the Voellmy model, which includes the resistance parameters $\mu$ and $\xi$ (described below).

Contrary to RAMMS, DAN3D is based on smoothed particle hydrodynamics (SPH) (Lucy, 1977; Gingold and Monaghan, 1977) to solve the governing equations resulting in flow depths, velocities and erosion thickness. Here the equations are solved in the center of reference columns and these mass particles are in the flow and progressed to a new position for each time step individually (Monaghan, 1989; Benz, 1990; Sosio et al., 2008). The SPH method uses the Langrangian reference frame and does not need a computational grid. DAN3D allows a selection of different types of resistance laws, including a laminar, turbulent, plastic, Bingham, frictional or Voellmy rheology (Hungr, 1995 and Hungr and McDougall, 2009 and references therein). For comparative reasons, in this study we only focused on the Voellmy rheology.

From theoretical reasoning, Voellmy (1955) divided total resistance of the flowing media into two parts: a Coulombtype friction (coefficient $\mu[-]$ ) that scales with the normal stress, and a turbulent drag coefficient $\xi\left[\mathrm{m} \mathrm{s}^{-2}\right]$ that scales with the velocity squared. A simplified representation of the total resistance $S[\mathrm{~Pa}]$ used in both simulation tools is as follows:

$S=\mu \rho H g \cos \phi+\left(\frac{\rho g U^{2}}{\xi}\right)$,

where $\rho$ is the bulk density, $g$ is gravitational acceleration, $\phi$ is the slope angle, $H$ is the mean flow height and $U$ is the mean flow velocity (Eq. 1). The snow avalanche and hillslope versions of RAMMS additionally offer the option of a velocity-dependent friction parameter for an improved representation of physical processes within the flow. In the version of RAMMS-DF used for this study, this option was not applied. Details of the random kinetic energy model can be found in Bartelt et al. (2006), Preuth et al. (2010) and Christen et al. (2010b).

In both simulation tools, modeling of internal pressure gradients is guided by Rankine's earth pressure theory, as similarly applied by Savage and Hutter (1989) (Bartelt et al., 1999; Hungr, 2008a). Here an internal friction angle con- trols the resulting stresses of longitudinal straining. A minimum value of the pressure coefficient $k$ appears when the flowing material extends under "active" conditions. In contrast, if the flow sheet is compressed, a maximum value results under "passive" conditions (Bartelt et al., 1999; Hungr and McDougall, 2009). DAN3D uses the approach of Savage and Hutter (1989) to calculate stress ratios parallel and perpendicular to the bed (Hungr, 2008a):

$k_{\mathrm{a} / \mathrm{p}}=2\left(\frac{1 \pm \sqrt{1-\cos ^{2} \phi_{\mathrm{i}}\left(1+\tan ^{2} \phi_{\mathrm{b}}\right)}}{\cos ^{2} \phi_{\mathrm{i}}}\right)-1$,

where $\phi_{\mathrm{i}}$ is the internal friction angle and $\phi_{\mathrm{b}}$ is the basal friction angle (representing the ratio of basal shear stress to total normal stress). In the case of $\phi_{\mathrm{b}}=0$ (basal friction is negligible compared to internal friction), Eq. (2) reduces to the classic Rankine form

$k_{\mathrm{a} / \mathrm{p}}=\tan ^{2}\left(45^{\circ} \pm \frac{\phi_{\mathrm{i}}}{2}\right)$,

which is implemented in RAMMS. Within our study we used the default values of $\phi_{\mathrm{i}}=35^{\circ}$ for DAN3D and a fixed value of $k_{\mathrm{a}}=k_{\mathrm{p}}=1$ for RAMMS. The consequences of this choice are discussed in Sect. 4.

\subsection{Input parameters, evaluation criteria and sensitivity analysis}

In engineering applications, the uncertainties are not only connected to the choice of flow resistance parameters $\mu$ and $\xi$, but also to the magnitude of an expected future event. Therefore, we performed a sensitivity analyses for both the RAMMS-DF and the DAN3D code by separately varying each of the Voellmy input parameters, $\mu$ and $\xi$, as well as the event magnitude (source volume), while keeping the other parameters constant. The variation in $\mu$ ranges from 0.01 to 0.32 , and $\xi$ from 100 to $1400 \mathrm{~m} \mathrm{~s}^{-2}$ and the initial volume was increased up to $100 \%$. For the Festeticgraben Creek in the Gesäuse area (Fig. 1b) we delineated the forested area beside the channel. We tested increased $\mu$ values (between 100 and $150 \%$ ) for the forested areas to account for the resilience of trees against the impact of debris-flows. No direct relation to calibrate the frictional parameters to the topography was considered.

As an initial condition, RAMMS-DF and DAN3D use a block release of source material of a predefined volume. RAMMS-DF additionally offers the possibility to define an inflow hydrograph at an arbitrary position in the channel. To keep boundary conditions consistent, we used a mass block release (e.g., an instantaneous landslide release) as the initial condition in both codes. Based on indications from aerial images, we assumed source areas in the upper part of catchments, with release heights of $\sim 1.5 \mathrm{~m}$ for the Pitztal and $\sim 0.5 \mathrm{~m}$ for the Gesäuse, resulting in total bulk volumes of 
$\sim 23000 \mathrm{~m}^{3}$ and $\sim 10000 \mathrm{~m}^{3}$, respectively, corresponding to observed deposition volumes. Sediment entrainment along the channel was neglected for all scenarios. All simulations performed in this study were made using grids based on airborne LIDAR DEMs with a $1 \mathrm{~m}$ resolution. To reduce calculation time and susceptibility of numerical instabilities during the calculation process, we effectively used a calculation grid of $2 \mathrm{~m}$ resolution for both case studies.

Because we do not have any reliable information on flow parameters in the transit reach during the events (i.e., flow depth, flow velocity), the evaluation of model performance focused solely on the deposition pattern. Since the event at Reiselehnrinne Creek as well as first simulation runs showed limited spreading of the material, the runout length of the simulated debris-flow deposits appeared to be the most useful evaluation criteria. Observed debris-flow material of the Festeticgraben Creek event in 2006 overtopped the channel and widely spread over the fan in form of tongues or lobes. We therefore compared observed and simulated deposition areas by using a similar approach to Carranza and Castro (2006) and Scheidl and Rickenmann (2010). For this, subareas $A_{x}, A_{x}$ and $A_{x}$, resulting from superposition of observed and simulated areas (Fig. 2), were systematically compared (Eqs. 4-6). Subsequently a coverage index $(\Omega)$ is derived using Eq. (7) and the closer $\Omega$ is to unity, the more accurate the simulation results are.

$$
\begin{aligned}
& \alpha=A_{x} / A_{\text {observed }}, \\
& \beta=A_{y} / A_{\text {observed }}, \\
& \gamma=A_{z} / A_{\text {observed }}, \\
& \Omega:=\alpha-\beta-\gamma .
\end{aligned}
$$

\section{Results}

\subsection{Back-analysis of the events}

First back-calculations of the event at the Reiselehnrinne Creek with both models led to differences to observed deposition patterns. Specifically, most of the material left the channel close to the distal limit of the fan and ran out straight into the forest instead of following the channelized path to the orographic right section of the fan (see dashed lines in Fig. 3a and c). To overcome this problem, we assigned an area with increased roughness $\left(\mu^{*}=0.9\right)$ at the left channel bank of the transit reach, that acted like a deflection dam. Subsequent simulations of both models were successful; the parameter set for the best-fit simulations using RAMMS-DF and DAN3D were: $\mu=0.11$ and $\xi=200 \mathrm{~m} \mathrm{~s}^{-2}$ and $\mu=0.08$ and $\xi=400 \mathrm{~m} \mathrm{~s}^{-2}$, respectively.

For the second study site (Festeticgraben, Gesäuse) we differentiated between the roughness within the channel $(\mu)$ and the roughness outside of the channel, which is expected to

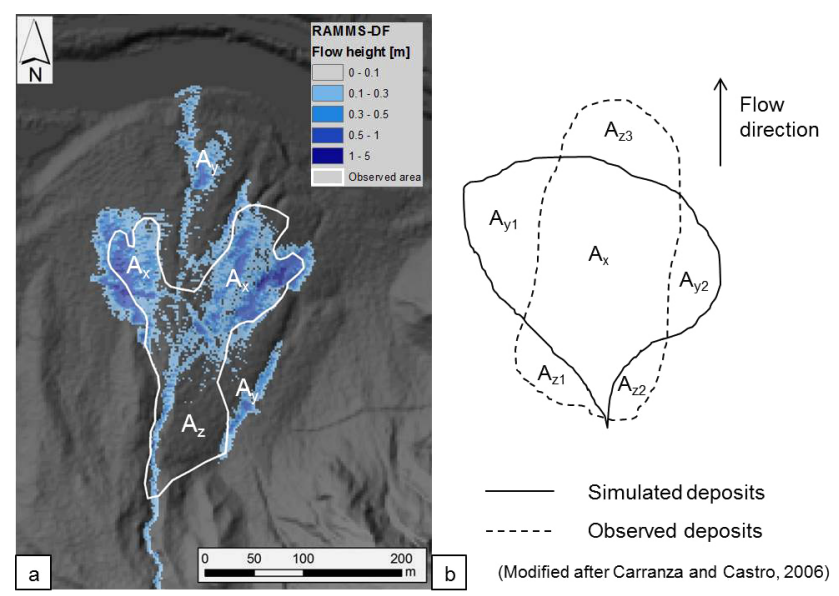

Figure 2. Superposition of the simulated area with the observed area of recently deposited debris-flow material at the Festeticgraben debris fan (a). Sub-areas were derived through superimposing the simulated deposits and the observed deposits (b) and following the approach of Carranza and Castro (2006), we assessed our simulation results. Area $A_{x}$ represents the simulated deposits within the observed area, whereas $A_{z}$ indicates the non-simulated debris-flow deposits within the observed area. Simulated deposition outside the observed area is shown as $A_{y}$.

be influenced by the forest stand $\left(\mu_{\mathrm{F}}\right)$. With this modification we obtained a satisfying fit between observed and simulated deposition areas for the RAMMS-DF model. DAN3D was less sensitive to the separation between channelized and non-channelized flow for $\mu$. Best-fit Voellmy parameters for the channelized flow at Festeticgraben were $\mu=0.07$ and $\xi=300 \mathrm{~m} \mathrm{~s}^{-2}$ for both simulation models (Fig. $3 \mathrm{~b}$ and d). The friction parameter representing the forest stand $\left(\mu_{\mathrm{F}}\right)$ was remarkably different between the models. We used $\mu_{\mathrm{F}}=0.23$ for the RAMMS-DF and $\mu_{\mathrm{F}}=0.07$, the same as for the channel, for the DAN3D code.

\subsection{Sensitivity analyses}

A sensitivity analysis was performed for $\mu, \xi$ and the initial volume for both simulation tools, RAMMS-DF and DAN3D. In all cases, while varying one parameter, the other parameters were kept constant at their best-fit values. As mentioned earlier, the most reasonable evaluation criteria for Reiselehnrinne Creek was the runout distance, whereas for the Festeticgraben, a comparison between observed and simulated deposition areas was considered. Figure 4 illustrates a comparison of the runout sensitivity against $\mu, \xi$ and the initial volume of the two models based on the case study site Reiselehnrinne. The Voellmy resistance parameters range from 0.03 to 0.16 for $\mu$, and from 100 to $700 \mathrm{~m} \mathrm{~s}^{-2}$ for $\xi$. Initial volumes were modified between 15000 and $50000 \mathrm{~m}^{3}$, reflecting a wide range of uncertainty during the hazard assessment. 


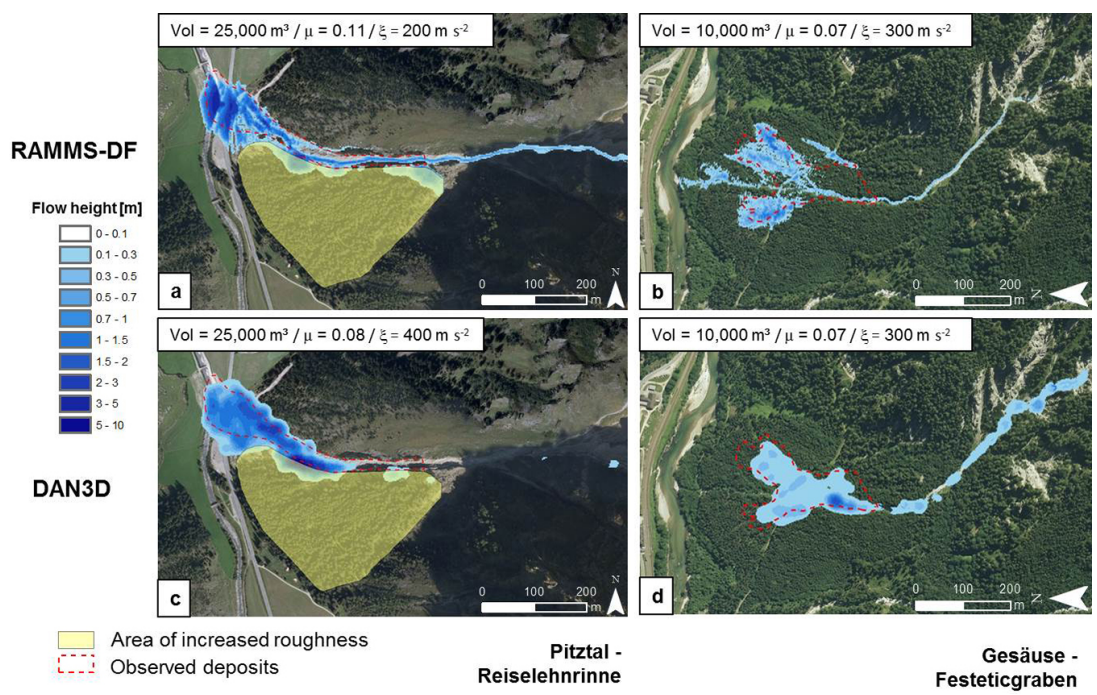

Figure 3. Best-fit simulations of RAMMS-DF and DAN3D for both study areas, the Reiselehnrinne (a and c) and the Festeticgraben (b and d; source aerial photo: National Park Gesäuse $\mathrm{GmbH}$ ). Deposition heights are represented using blue color shading, for the results for the event in 2009 at the Reiselehnrinne Creek as well as for the event in 2006 at the Festeticgraben Creek. The red dashed lines represent the observed deposits. Areas of increased roughness are depicted in light yellow.

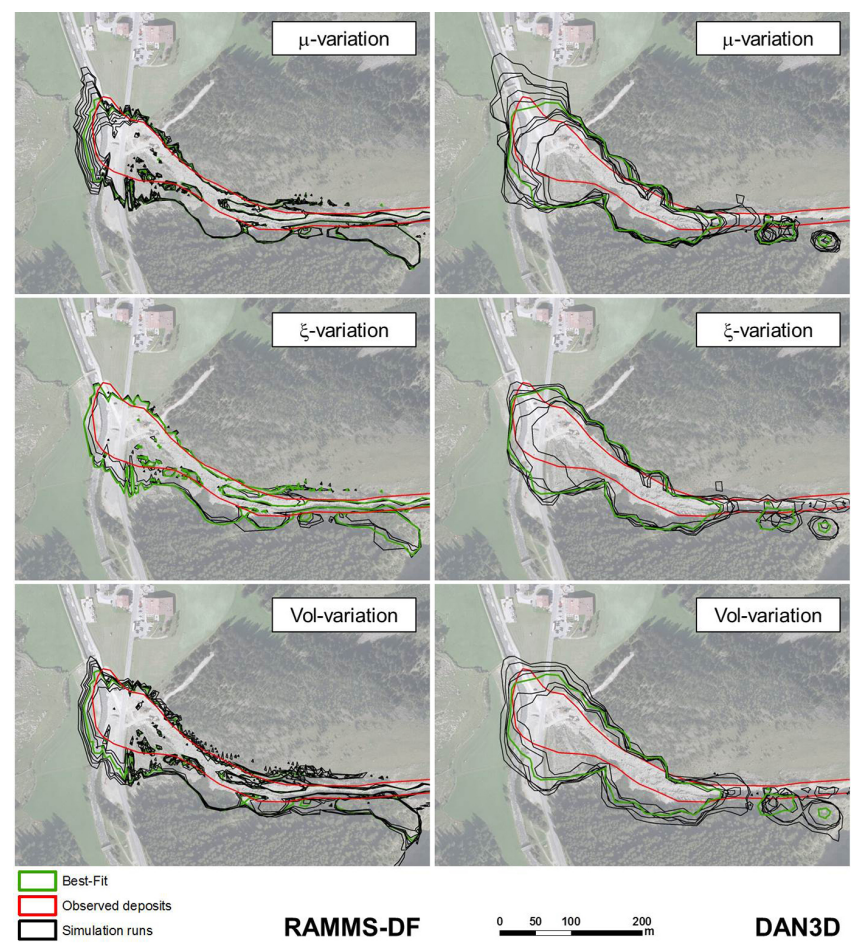

Figure 4. Variation of the Voellmy parameters (0.03-0.16 for $\mu$ and $100-700 \mathrm{~m} \mathrm{~s}^{-2}$ for $\xi$ ) and the initial volume (from 15000 to $50000 \mathrm{~m} \mathrm{~s}^{-2}$ ) for the RAMMS-DF and the DAN3D codes for the Pitztal study area. When varying one parameter, the others were kept constant. Outlines of the simulation runs are given in black, and the best-fit simulation in green. The observed deposits of the event in 2009 are presented in red.
In the case of the Festeticgraben Creek, the evaluation parameter $\Omega$ gives an indication of the quality of the simulated debris-flow pattern relative to the observed deposits, with $\Omega=1$ representing a perfect match. Note that material which was deposited in the transit zone before reaching the fan was neglected. We varied the Voellmy parameters from 0.01 to 0.24 for $\mu$ and 100 to $1400 \mathrm{~m} \mathrm{~s}^{-2}$ for $\xi$. Different initial volumes between 10000 and $20000 \mathrm{~m}^{3}$ were tested. We additionally varied the roughness of the area outside of the channel $\left(\mu_{\mathrm{F}}\right)$ between 0.03 and 0.32 . Intermittent variation steps are the same for both models. Generally we detected a higher sensitivity of the friction parameter $\mu$ than of the turbulent coefficient $\xi$ (Fig. 5). This is mainly due to the form of the Voellmy equation, for which the Coulomb-friction term dominates flow resistance at low speeds (e.g., in the deposition zone), whereas the turbulent term becomes relevant when the flow is fast (e.g., in the transit zone). Because we only evaluate deposition pattern on the fan rather than flow parameters $(v, h)$ in the transit zone, this sensitivity pattern is expected. Comparing sensitivity between simulation models, we find that RAMMS-DF is rather insensitive to parameter variations compared to DAN3D.

\section{Discussion}

First simulation runs did not match the observed deposition pattern for both investigation areas. In the case of the Reiselehnrinne, most of the material left the channel before it reached the proximal limit of the fan. This was not observed after the event in 2009. This discrepancy is most likely due to (1) the use of an outdated or insufficiently precise DEM, 

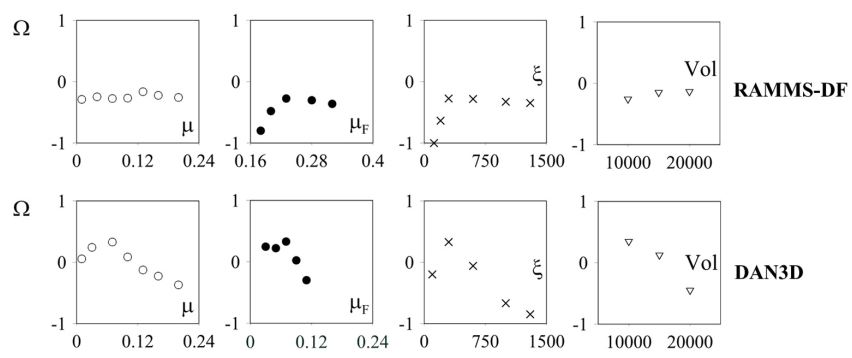

Figure 5. Sensitivity of the dimensionless $\Omega$ value (Eq. 7) to $\mu, \mu_{\mathrm{F}}$, $\xi$ and the initial volume for the Gesäuse case study for both simulation models. While varying one parameter, the other parameters were kept constant.

(2) erosion/deposition processes during the event itself, or (3) an overestimation of simulated flow depth. We have no data to quantify these effects, but we can make qualitative assessments. The grid size of the DEM used in this study was set to $2 \mathrm{~m}$ to reduce the calculation time and yet provide simulation results with a relatively high spatial resolution. Resulting simulated maximum flow depths between 5 and $10 \mathrm{~m}$ are plausible for both model results. However, the DEM used in our calculations was derived by air-borne laser scanning 3 years before the event occurred and therefore does not account for potential morphological changes in the meantime. In an earlier study, Kogelnig-Mayer et al. (2011) reconstructed debris-flows and snow avalanches back to 1868 by tree ring analysis. The results showed that no debris-flow events were detectable between 2006 and 2009. Therefore morphological changes in the channel are expected to be mainly due to fluvial processes. For practical engineering applications, there are several ways to direct the flow in a certain direction, including modification of the DEM (adding a dam structure or changing the height in the original grid of the DEM), change of resistance parameters of the flowing mass along the channel (thereby altering the shape of the hydrograph), or localized increase of roughness of one channel bank. We chose the latter approach and increased the left channel bank roughness to $\mu^{*}=0.9$ (yellow shaded area in Fig. 3). This leads to deposition along the left channel bank and acts like a deflection dam.

For the second study site at the Festeticgraben Creek we assumed that the forested fan has considerably influence on the deposition behavior of debris-flows and separated $\mu$ values between friction within the channel and outside of the channel. Others have addressed the significance of interactions between forest and snow avalanches (e.g., Teich, 2013; Feistl et al., 2014) which can be accounted for by adjusting the Voellmy friction parameters for simulations. For the RAMMS-AV model, resistance parameters for forested areas of $\mu=0.02$ and $\xi=400 \mathrm{~m} \mathrm{~s}^{-2}$ for all magnitudes of avalanches can be found in the handbook (Bartelt et al., 2013a), but yet few suggestions are available for debris-flows. Within this study we increased $\mu_{\mathrm{F}}$ for
RAMMS-DF to 0.23 , whereas for DAN3D best results were returned with the same value of $\mu$ within and outside of the channel. Similarly, Hauser (2011) increased the channel friction parameter only in a minor way, from $\mu=0.25$ to $\mu_{\mathrm{F}}=0.27$ to account for roughness due to a forest when reproducing a $\sim 70000 \mathrm{~m}^{3}$ debris-flow event in Switzerland with RAMMS-DF. Subsequent sensitivity analysis showed that the output of RAMMS-DF is mainly sensitive to variations in $\mu_{\mathrm{F}}$ rather than to variations in $\mu$ in the channel. For DAN3D, $\mu$ and $\mu_{\mathrm{F}}$ influence results similarly.

Though we used the same input parameters for both models, there are several differences between the simulation programs leading to the results (Table 1). The main differences arise from different stopping criteria, calculation of the pressure term, and the numerical solution schemes of the mass and momentum conservation equations. For quantifying the effect of the different stopping criteria, we conducted some additional simulations to evaluate the repeatability and relative sensitivity of the outcomes. RAMMS-DF stops calculation at a user-defined percentage value of the total mass momentum (or it can be stopped manually or after a userdefined run duration). In this study we consistently used a value of $15 \%$. Changing this stopping criteria to other plausible values $(5,10$ and $20 \%)$, indicates that the overall sensitivity can be similar to that of the variation in $\mu$ (Fig. 6). Alternatively, choosing a much larger threshold leads to unrealistically early stopping, while very small thresholds may cause numerical diffusion of the simulation results (Bartelt et al., 2013b). The DAN3D code can be stopped manually or automatically after a predetermined duration. Here we manually stopped the simulation when the flow front visually came to a halt. This method is expected to be biased to some extent, but repeating identical runs gave confidence in the repeatability of our simulations.

Another difference between RAMMS and DAN3D is the effect of vertical pressure gradients on the internal stress state in the 2-D momentum balance equations, which is modeled by a proportionality coefficient $k_{\mathrm{a} / \mathrm{p}}$ (e.g., Hungr and McDougall 2009, Eqs. 10-11, and Christen et al., 2010a, Eqs. 2-3). This pressure coefficient is defined differently in both models. DAN3D calculates $k_{\mathrm{a} / \mathrm{p}}$ by Eq. (2), which is based on Savage and Hutter's (1989) adoption of Rankine's earth pressure theory, accounting for a deviation of the direction of principal stresses from flow direction due to significant basal resistance (Hungr and McDougall, 2009). Hungr (2008a) elaborates that in the case of strong pressure gradients, this approximation is imprecise and leads to significant deviations from experimental observations, especially in the initial phase of a dam break situation. For these situations Hungr (2008a) suggests an empirical equation to modify $\phi_{\mathrm{b}}$. In the current study we expect this effect to be minor and only Eq. (2) was applied, using an internal friction angle of $35^{\circ}$, which is realistic for debris-flow material. RAMMS simplifies the classic Rankine approach (Eq. 3) by setting $k_{\mathrm{a}}=k_{\mathrm{p}}$ (Bartelt et al., 1999, 2013a). In our study we used the default 
Table 1. Comparison of model input conditions within our study. Grids, triggering conditions, excluded erosion, rheology and the governing equations are identical, whereas the numerical solution, the reference system as well as the stopping of the simulations are different.

\begin{tabular}{|c|c|c|}
\hline & RAMMS-DF & DAN3D \\
\hline Depth-averaged shallow water equations conserving mass and momentum & $\sqrt{ }$ & $\sqrt{ }$ \\
\hline Friction relation used & Voellmy & Voellmy \\
\hline Numerical solution scheme & FVM (finite volume) & SPH (smoothed particle hydrodynamics) \\
\hline Reference system & Eulerian framework & Lagrangian framework \\
\hline Grid & Fixed grid in the space & Affiliated to the flowing material \\
\hline DEM resolution & $1 \mathrm{~m}$ & $1 \mathrm{~m}$ \\
\hline Source & Block release mass & Block release mass \\
\hline Erosion & Neglected in this study & Neglected in this study \\
\hline Stopping criteria & Percentage of momentum & End of visual movement \\
\hline Pressure term & $k_{\mathrm{a}}=k_{\mathrm{p}}=1$ & Dynamic $k_{\mathrm{a} / \mathrm{p}}$ (Eq. 2) \\
\hline
\end{tabular}

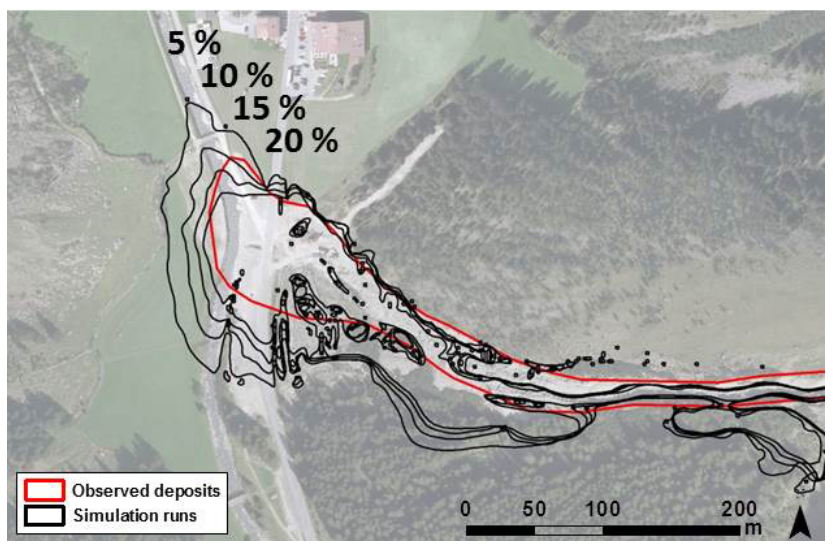

Figure 6. Variations of stopping criteria using the RAMMS-DF model for the Reiselehnrinne Creek case study. Outlines of the simulations are presented in black; observed deposits are given in red.

value of 1 which corresponds to a hydrostatic stress distribution. Variations in $k_{\mathrm{a} / \mathrm{p}}$ by a factor of 2-3 had similar effects on the runout as variation of the Voellmy friction parameter $\mu$ (Bartelt et al., 2013b). The effect of the method for describing the earth pressure would also influence the runout in a similar way, but it may also change the mobility of the flow in general.

Besides these differences in program code, there are also other factors that may influence model output, like the question of DEM and calculation resolution (Rickenmann et al., 2006; Hungr, 2008b; Christen et al., 2010a; Bühler et al., 2011), or erosion along the path (e.g., Hungr, 1995; McDougall and Hungr, 2005; Christen et al., 2010b; Berger et al., 2011). Effects of both were not investigated in this study.

A general observation is that for both programs, changing the friction parameter $\mu$ has a stronger influence on the runout distances of the simulated debris-flows than varying the $\xi$ value in the case of the Pitztal area. This is in accordance to expectations, because other studies have also shown that $\xi$ is mainly responsible for the flow behavior along the channel and $\mu$ determines runout (e.g., Barbolini et al., 2000). A similar sensitivity behavior is observed for the evaluation parameter $\Omega$ at the second test site, Festeticgraben Creek. Interestingly, the variation in the initial volume provides little variation in the output of RAMMS-DF for both of our study sites. In contrast, DAN3D shows more pronounced sensitivity to initial volume variations, but sensitivity is similar as for the variation of resistance parameters. This moderate sensitivity to event magnitude uncertainty of $\pm 20 \%$ may be considered for engineering scenario design for runout prediction.

For the simulation of our small alpine debris-flow events, the best-fit Voellmy parameter sets of RAMMS-DF and DAN3D are in the range of $\mu=0.07-0.11$ and $\xi=200$ $400 \mathrm{~m} \mathrm{~s}^{-2}$ for channelized flows and with $\mu$ values up to 0.23 for forested areas outside of the channel. To compare our results, we plot the $\mu-\xi$ parameter space together with other published values from simulations with DAN3D and RAMMS, including rock avalanches, snow avalanches and other debris-flows according to their magnitudes (Fig. 7). We also included values of the 1-D version of DAN, which uses the same equations of motion and the simplifying concept of equivalent fluid; see Hungr (2008b), Hungr and McDougall (2009) for details. We find that $\mu$ and $\xi$ values for debrisflows are rather low compared to other processes, indicating lower velocities in the transit zones, but larger runout in the deposition zone. A study performed by Scheidl et al. (2013), in which several back-calculated debris-flow events were compared based on the Voellmy friction relation, is in agreement with our results. Rock avalanches (most often modeled with DAN3D) tend to have $\mu$ values in a similar range, but mostly higher $\xi$ values. Ice-rock avalanches were similarly simulated with high $\xi$ parameters, but much lower $\mu$ values, consistent for DAN3D and RAMMS. This parameter space may reflect lower friction of the ice and the presence of porewater due to melting of the ice (Schneider et al., 2011). The parameter space shown for snow avalanches are suggested values (Bartelt et al., 2013a), based on experience of back-calculated observed snow avalanches. The Voellmy parameters are rather large and represent the envelope of parameter space currently available for geophysical flows. The 

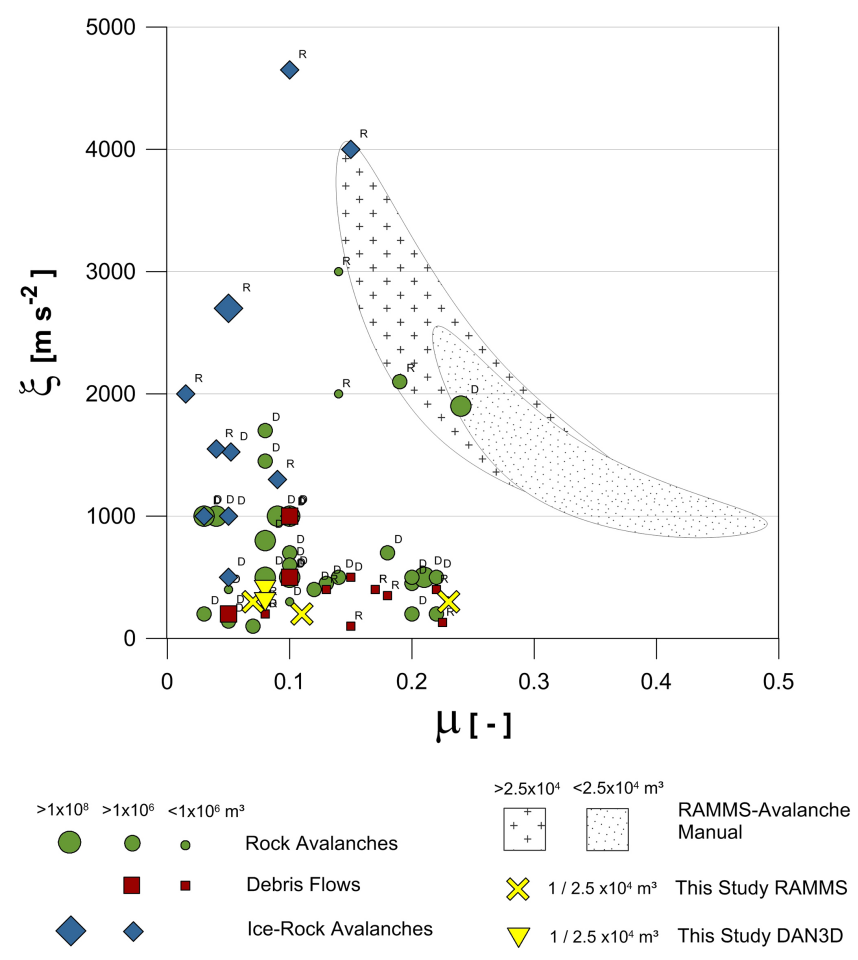

Figure 7. Voellmy resistance parameter sets from back-calculation of different events with RAMMS $\left({ }^{\mathrm{R}}\right)$ and DAN(3D) $\left({ }^{\mathrm{D}}\right)$. Debrisflow parameters from our study are presented as yellow crosses and triangles, respectively. Debris-flow parameters from other studies (Scheidl et al., 2013; McDougall et al., 2006; Hungr et al., 2002; Hungr, 2008b; Bartelt et al., 2013b; Jakob et al., 2000), are given as brown squares. Rock avalanches are illustrated as green circles and ice-rock avalanches are denoted by blue diamonds (Pirulli et al., 2004; Hungr and Evans, 1996, 2004; Hungr and McDougall, 2009; Hungr, 2008b; Evans et al., 2007; Allen et al., 2009; Sosio et al., 2008; Lipovsky et al., 2008; Schneider et al., 2010). Suggested parameter ranges for small $\left(<25000 \mathrm{~m}^{3}\right)$ and large $\left(>25000 \mathrm{~m}^{3}\right)$ snow avalanches are given in two different shaded areas (Bartelt et al., 2013a).

data show that $\mu$ decreases and $\xi$ increases with increasing event volume, reflecting higher velocities and larger runout for large avalanches. Searching for a similar relation in published data available for other processes, we only found a weak trend for rock avalanches.

\section{Conclusions}

Two documented debris-flow events in Austria were backcalculated with two different simulation tools, the RAMMSDF code and the DAN3D code: the Reiselehnrinne Creek (Pitztal) event in 2009, which released a total volume of $\sim 23000 \mathrm{~m}^{3}$, and a debris-flow in the Festeticgraben Creek (Gesäuse), which delivered $\sim 10000 \mathrm{~m}^{3}$ of material to the fan. Areas of increased roughness were included to account for additional surface roughness due to the interaction of the flow with the forest. Best-fit parameter sets for both models and for both study sites are in a similar range ( $\mu=0.07-0.11$ and $\xi=200-400 \mathrm{~m} \mathrm{~s}^{-2}$ ), which is in accordance with the experience of other studies. Focusing only on deposition pattern, sensitivity analyses using two different evaluation criteria showed a significant sensitivity to the variation in $\mu$ and event volume, and lower sensitivity to variation in $\xi$. DAN3D and RAMMS-DF react differently to the variation of input parameters, which might be due to different numerical solution schemes to solve the depth-averaged equations of motion in the models or due to the calculation of the resultant of the internal pressure gradients in the momentum equations. For an improved engineering hazard assessment, more experience on a reasonable Voellmy parameter range for debrisflows is desirable. Additionally, future simulations of debrisflows using the Voellmy model may be useful to differentiate between different types of surface roughness, with the goal of providing a database of recommended model parameters.

Acknowledgements. This project received financial support from the Climate and Energy Fund and is carried out within the framework of the "ACRP" Program. The authors would like to thank Oldrich Hungr for providing the DAN3D code to perform our simulations within this study and for helpful discussion.

Edited by: F. Guzzetti

Reviewed by: C. Huggel and one anonymous referee

\section{References}

Allen, S. K., Schneider, D., and Owens, I. F.: First approaches towards modelling glacial hazards in the Mount Cook region of New Zealand's Southern Alps, Nat. Hazards Earth Syst. Sci., 9, 481-499, doi:10.5194/nhess-9-481-2009, 2009.

Ancey, C.: Plasticity and geophysical flows: a review, J. Non-Newton. Fluid Mech., 142, 4-35, doi:10.1016/j.jnnfm.2006.05.005, 2006.

Barbolini, M., Gruber, U., Keylock, C. J., Naaim, M., and Savi. F.: Application of statistical and hydraulic-continuum dense-snow avalanche models to five real European sites, Cold Reg. Sci. Technol., 31, 133-149, doi:10.1016/S0165-232X(00)00008-2, 2000.

Bartelt, P., Salm, B., and Gruber, U.: Calculating dense-snow avalanche run-out using a Voellmy-fluid model with active/passive longitudinal straining, J. Glaciol., 45, 242-254, doi:10.3189/002214399793377301, 1999.

Bartelt, P, Buser, O., and Platzer, K.: Fluctuation-dissipation relations for granular snow avalanches, J. Glaciol., 52, 631-643, doi:10.3189/172756506781828476, 2006.

Bartelt, P., Bühler, Y., Christen, M., Deubelbeiss, Y., Salz, M., Schneider, M., and Schumacher, L.: RAMMS-AV User Manual, WSL Institute for Snow and Avalanche Research SLF, Davos, Birmensdorf, Switzerland, available at: http://ramms.slf. ch/ramms/, last access: 28 January 2015, 2013a.

Bartelt, P., Bühler, Y., Christen, M., Deubelbeiss, Y., Graf, C., McArdell, B. W., Salz, M., and Schneider, M.: RAMMS-DF 
User Manual, WSL Institute for Snow and Avalanche Research SLF, Davos, Birmensdorf, Switzerland, available at: http: //ramms.slf.ch/ramms/, last access: 28 January 2015, $2013 \mathrm{~b}$.

Benz, W.: Smooth particle hydrodynamics: a review, in: The Numerical Modelling of Nonlinear Stellar Pulsations, edited by: Buchler, J. R., Kluwer Academic, Dordrecht, 269-288, 1990.

Berger, C., McArdell, B. W., and Schlunegger, F.: Direct measurement of channel erosion by debris flows,Illgraben, Switzerland, J. Geophys. Res., 16, F01002, doi:10.1029/2010JF001722, 2011.

Bühler, Y., Christen, M., Kowalski, J., and Bartelt, P.: Sensitivity of snow avalanche simulations to digital elevation model quality and resolution, Ann. Glaciol., 52, 72-80, doi:10.3189/172756411797252121, 2011.

Carranza, E. J. M. and Castro, O. T.: Predicting lahar-inundation zones: case study in West Mount Pinatubo, Philippines, Nat. Hazards, 37, 331-372, doi:10.1007/s11069-005-6141-y, 2006.

Christen, M., Bartelt, P., and Gruber, U.: Numerical calculation of snow avalanche runout distances, in: Computing in Civil Engineering, Proceeding of the 2005 International Conference, edited by: Soibelman, L. and Pena-Mora, F., Cancun, Mexico, 12-15 July 2005.

Christen, M., Bartelt, P., Kowalski, J., and Stoffel, L.: Calculation of dense snow avalanches in three-dimensional terrain with the numerical simulation programm RAMMS, in: International Snow Science Workshop 2008, Proceedings, 21-27 September, Whistler, BC, CAN, 709-716, 2008.

Christen, M., Bartelt, P., and Kowalski, J.: Back calculation of the In den Arelen avalanche with RAMMS: interpretation of model results, Ann. Glaciol., 51, 161-168, doi:10.3189/172756410791386553, 2010a

Christen, M., Kowalski, J., and Bartelt, P.: RAMMS: numerical simulation of dense snow avalanches in threedimensional terrain, Cold Reg. Sci. Technol., 63, 1-14, doi:10.1016/j.coldregions.2010.04.005, 2010b.

Contreras, S. M. and Davies, T. R.: Coarse-grained debris flows: hysteresis and time-dependent rheology, J. Hydraul. Eng., 126, 938-941, 2000.

Deline, P., Alberto, W., Broccolato, M., Hungr, O., Noetzli, J., Ravanel, L., and Tamburini, A.: The December 2008 Crammont rock avalanche, Mont Blanc massif area, Italy, Nat. Hazards Earth Syst. Sci., 11, 3307-3318, doi:10.5194/nhess-11-33072011, 2011.

Evans, S. G., Guthrie, R. H., Roberts, N. J., and Bishop, N. F.: The disastrous 17 February 2006 rockslide-debris avalanche on Leyte Island, Philippines: a catastrophic landslide in tropical mountain terrain, Nat. Hazards Earth Syst. Sci., 7, 89-101, doi:10.5194/nhess-7-89-2007, 2007

Feistl, T., Bebi, P., Teich, M., Bühler, Y., Christen, M., Thuro, K., and Bartelt, P.: Observations and modeling of the braking effect of forests on small and medium avalanches, J. Glaciol., 60, 124 138, doi:10.3189/2014JoG13J055, 2014.

Gingold, R. A. and Monoghan, J. J.: Smoothed particle hydrodynamics: theory and application to nonsperical stars, Mon. Not. R. Astron. Soc., 181, 375-389, doi:10.1093/mnras/181.3.375, 1977.

GIS-Steiermark: http://www.gis.steiermark.at, last access: 25 November 2013.

Graf, C. and McArdell, B. W.: Simulation of debris flow run out before and after construction of mitigation measures: an example from the Swiss Alps, in: Debris Flows: Disasters, Risk, Forecast, Protection, edited by: Chernomorets, S. S., Proceedings of the International Conference, Pyatigorsk, Russia, 22-29 September 2008, Sevkavgiprovodkhoz Institute, Pyatigorsk, 233-236, 2008.

Gray, J. M. N. T., Wieland, M., and Hutter, K.: Gravitydriven free surface flow of granular avalanches over complex basal topography, P. Roy. Soc. Lond. A, 455, 1841-1874, doi:10.1098/rspa.1999.0383, 1999.

Hauser, D.: Interaktion Murgang - Wald: Rekonstruktion von Ereignissen mit Hilfe von RAMMS, MS Thesis, Department of Environmential Systems Science, Swiss Federal Institute of Technology, Zurich, 2011.

Hungr, O.: A model for the runout analysis of rapid flow slides, debris flows, and avalanches, Can. Geotech. J., 32, 610-623, 1995.

Hungr, O.: Simplified models of spreading flow of dry granular material, Can. Geotech. J., 45, 1156-1168, 2008a.

Hungr, O.: Numerical modelling of the dynamics of debris flows and rock avalanches, Geomech. Tunnelb., 1, 112-119, doi:10.1002/geot.200800010, 2008b.

Hungr, O. and Evans, S. G.: Rock avalanche runout prediction using a dynamic model, in: Proceedings of the Seventh International Symposium on Landslides, Trondheim, Norway, 1, 233 238, 1996.

Hungr, O. and Evans, S. G.: Entrainment of debris in rock avalanches: An analysis of a long run-out mechanism, Geol. Soc. Am. Bull., 116, 1240-1252, doi:10.1130/B25362.1, 2004.

Hungr, O. and McDougall, S.: Two numerical models for landslide dynamic analysis, Comput. Geosci., 35, 978-992, doi:10.1016/j.cageo.2007.12.003, 2009.

Hungr, O., Dawson, R., Kent, A., Campbell, D., and Morgenstern, N. R.: Rapid flow slides of coal-mine waste in British Columbia, Canada, in: Catastrophic Landslides: Effects, Occurrence, and Mechanisms, v. XV, edited by: Evans, S. G. and DeGraff, J. V., Geol. Soc. Am. Rev. Eng. Geol., 33, 191-208, 2002.

Hungr, O., Corominas, J., and Eberhardt, E.: Estimating landslide motion mechanism, travel distance and velocity, in: Landslide Risk Management, edited by: Hungr, O., Fell, R., Couture, R., and Eberhardt, E., Taylor \& Francis Group, Vancouver, 99-128, 2005.

Hürlimann, M., Rickenmann, D., Medina, V., and Bateman, A.: Evaluation of approaches to calculate debris-flow parameters for hazard assessment, Eng. Geol., 102, 152-163, doi:10.1016/j.enggeo.2008.03.012, 2008.

Iverson, R. M.: The physics of debris flows, Rev. Geophys., 35, 245-296, 1997.

Iverson, R. M.: The debris flow rheology myth, in: Proceedings of the 3rd International Conference on Debris flow Hazard Mitigation: Mechanics, Prediction and Assessment, edited by: Rickenmann, D. and Chen, C.-L., Davos, Millpress, Rotterdam, 303314, 2003.

Iverson, R. M. and Denlinger, R. P.: Flow of variably fluidized granular masses across three-dimensional terrain, 1. Coulomb mixture theory, J. Geophys. Res., 106, 537-552, doi:10.1029/2000JB900329, 2001.

Jakob, M., Anderson, D., Fuller, T., Hungr, O., and Ayotte, D.: An unusually debris flow at Hummingbird Creek, Mara Lake, British Columbia, Can. Geotech. J., 37, 1109-1125, 2000. 
Kaitna, R. and Rickenmann, D.: A new experimental facility for laboratory debris flow investigation, J. Hydraul. Res., 45, 797810, doi:10.1080/00221686.2007.9521817, 2007.

Kaitna, R., Rickenmann, D., and Schatzmann, M.: Determination of rheologic information from laboratory experiments, Acta Geotech., 2, 71-85, 2007.

Kaitna, R., Dietrich, W. E., and Hsu, L.: Surface slopes, velocity profiles and fluid pressure in coarse-grained debris flows saturated with water and mud, J. Fluid Mech., 741, 377-403, doi:10.1017/jfm.2013.675, 2014.

Kogelnig-Mayer, B., Stoffel, M., Schneuwly-Bollschweiler, M., Hübl, J., Rudolf-Miklau, F.: Possibilities and limitations of dendrogeomorphic time-series reconstructions on sites influenced by debris flows and frequent snow avalanche activity, Arct. Antarct. Alp. Res., 43, 649-658, 2011.

Körner, H. J.: Reichweite und Geschwindigkeit von Bergstürzen und Fliesslawinen, Rock Mech., 8, 225-256, 1976.

Legros, F.: The mobility of long-runout landslides, Eng. Geol., 63, 301-331, 2002.

Lipovsky, P. S., Evans, S. G., Clague, J. J., Hopkinson, C., Couture, R., Bobrowsky, P., Ekström, G., Demuth, M. N., Delaney, K. B., Roberts, N. J., Clarke, G., and Saeffer, A.: The July 2007 rock and ice avalanches at Mount Steele, St. Elias Mountains, Yukon, Canada, Landslides, 5, 445-455, doi:10.1007/s10346-008-01334, 2008.

Lucy, L. B.: A numerical approach to testing the fission hypothesis, Astron. J., 82, 1013-1024, 1977.

Major, J. J. and Pierson, T.: Debris flow rheology: experimental analysis of fine-grained slurries, Water Resour. Res., 28, 841857, doi:10.1029/91WR02834, 1992.

McDougall, S. and Hungr, O.: Modeling of landslides which entrain material from the path, Can. Geotech. J., 42, 1437-1448, 2005.

McDougall, S., Boultbee, N., Hungr, O., Stead, D., and Schwab, J. W.: The Zymoetz River landslide, British Columbia, Canada:description and dynamic analysis of a rock slide-debris flow, Landslides, 3, 195-204, doi:10.1007/s10346-006-0042-3, 2006.

Medina, V., Hürlimann, M., and Bateman, A.: Application of FLATModel, a 2D finite volume code, to debris flows in the northeastern part of the Iberian Peninsula, Landslides, 5, 127-142, doi:10.1007/s10346-007-0102-3, 2008.

Monaghan, J. J.: On the problem of penetration in particle methods, J. Comput. Phys., 82, 1-15, doi:10.1016/0021-9991(89)90032-6, 1989.

Naef, D., Rickenmann, D., Rutschmann, P., and McArdell, B. W: Comparison of flow resistance relations for debris flows using a one-dimensional finite element simulation model, Nat. Hazards Earth Syst. Sci., 6, 155-165, doi:10.5194/nhess-6-1552006, 2006.

O'Brien, J. S., Julien, P. Y., and Fullerton, W. T.: Two-dimensional water flood and mudflow simulation, J. Hydraul. Eng., 119, 244 261, doi:10.1061/(ASCE)0733-9429(1993)119:2(244), 1993.

Pastor, M., Quecedo, M., Fernandez Merodo, J. A., Herrores, M. I., Gonzalez, E., and Mira, P.: Modelling tailings dams and mine waste dumps failures, Geotechnique, 52, 579-591, doi:10.1680/geot.2002.52.8.579, 2002.

Phillips, C. J. and Davies, T. R. H.: Determining rheological parameters of debris flow material, Geomorphology, 4, 101-110, 1991.
Pirulli, M., Scavia, C., and Hungr, O.: Determination of rock avalanche run-out parameters through back analyses, in: Landslides: Evaluation and Stabilization, edited by: Lacerda, W. A., Ehrlich, M., Fontoura, S. A. B., and Sayao, A. S. F., Proceedings of the Ninth International Symposium on Landslides, June 28-July 2 2004, Taylor \& Francis Group, Rio de Janeiro, Brazil, 1361-1366, doi:10.1201/b16816-194, 2004.

Preuth, T., Bartelt, P., Korup, O., and McArdell, B. W.: A random kinetic energy model for rock avalanches: eight case studies, J. Geophys. Res., 115, F03036, doi:10.1029/2009JF001640, 2010.

Revellino, P., Hungr, O., Guadagno, F. M., and Evans, S. G.: Velocity and runout simulation of destructive debris flows and debris avalanches in pyroclastic deposits, Campania region, Italy, Environ. Geol., 45, 295-311, doi:10.1007/s00254-003-0885-z, 2004.

Rickenmann, D.: Empirical relationships for debris flows, Nat. Hazards, 19, 47-77, doi:10.1023/A:1008064220727, 1999.

Rickenmann, D., Laigle, D., McArdel, B. W., and Hübl, J.: Comparison of 2D debris-flow simulation models with field events, Comput. Geosci., 10, 241-264, doi:10.1007/s10596-005-90213, 2006.

Savage, S. B. and Hutter, K.: The motion of a finite mass of granular material down a rough incline, J. Fluid Mech., 199, 177-215, doi:10.1017/S0022112089000340, 1989.

Scheidegger, A. E.: On the prediction of the reach and velocity of catastrophic landslides, Rock Mech., 5, 231-236, doi:10.1007/BF01301796, 1973.

Scheidl, C. and Rickenmann, D.: Empirical prediction of debrisflow mobility and deposition on fans, Earth Surf. Proc. Land., 35, 157-173, doi:10.1002/esp.1897, 2010.

Scheidl, C., Rickenmann, D., and McArdell, B. W.: Runout prediction of debris flows and similar mass movements, Landslide Sci. Pract., 3, 221-229, doi:10.1007/978-3-642-31310-3_30, 2013.

Schneider, D., Bartelt, P., Caplan-Auerbach, J., Christen, M., Huggel, C., and McArdell, B. W.: Insights into rock-ice avalanche dynamics by combined analysis of seismic recordings and a numerical avalanche model, J. Geophys. Res., 115, F04026, doi:10.1029/2010JF001734, 2010.

Schneider, D., Huggel, C., Haeberli, W., and Kaitna, R.: Unraveling driving factors for large rock-ice avalanche mobility, Earth Surf. Proc. Land., 36, 1948-1966, doi:10.1002/esp.2218, 2011.

Schraml, K., Oismüller, M., Stoffel, M., Hübl, J., and Kaitna, R.: Debris-flow activity in five adjacent gullies in a limestone mountain range, Geochronometria, 42, 60-66, doi:10.1515/geochr2015-0007, 2015.

Sosio, R., Crosta, G. B., and Hungr, O.: Complete dynamic modeling calibration for the Thurwieser rock avalanche (Italian Central Alps), Eng. Geol., 100, 11-26, doi:10.1016/j.enggeo.2008.02.012, 2008.

Takahashi, T.: Debris Flow, International Association for Hydraulic Research Monograph, A. A. Balkema, Rotterdam, 1991.

Teich, M.: Snow avalanches in forested terrain, PhD thesis, Department of Civil, Environmental and Geomatic Engineering, ETH Zurich, Switzerland, 2013.

Toro, E. F.: Riemann Solvers and Numerical Methods for Fluid Dynamics, 2nd Edn., Springer-Verlag, Berlin, 1999.

Voellmy, A.: Über die Zerstörungskraft von Lawinen, Schweizerische Bauzeitung, 73, 212-285, 1955. 